\title{
DEVELOPING ITEMS FOR MEASURING QUALITY OF WORK LIFE AMONG MALAYSIAN ACADEMICS: AN EXPLORATORY FACTOR ANALYSIS PROCEDURE
}

\author{
Amauche Ehido $^{1 *}$, Zainudin Awang ${ }^{2}$, Bahyah Abdul Halim ${ }^{3}$, Chukwuebuka Ibeabuchi ${ }^{4}$ \\ ${ }^{1 *}$ Doctoral Research Fellow, Faculty of Business and Management, Universiti Sultan Zainal Abidin (UniSZA), Malaysia; \\ ${ }^{2}$ Professor, Faculty of Business and Management, Universiti Sultan Zainal Abidin (UniSZA), Malaysia; ${ }^{3}$ Senior Lecturer, \\ Faculty of Business and Management, Universiti Sultan Zainal Abidin (UniSZA), Malaysia; ${ }^{4}$ Researcher, School of \\ International Studies, College of Law, Government and International Studies, Universiti Utara, Malaysia. \\ Email: ${ }^{1}$ jehido@yahoo.com, ${ }^{2}$ zainudinawang@unisza.edu.my, ${ }^{3}$ bahyahahalim@unisza.edu.my, ${ }^{4}$ princenabis@yahoo.com
}

Article History: Received on $20^{\text {th }}$ January 2020, Revised on $25^{\text {th }}$ April 2020, Published on $29^{\text {th }}$ June 2020

\begin{abstract}
Purpose of the study: Quality of work life (QWL) is vital for all establishments to continue to hire and retain highperformance workers. However, from the review of previous literature on QWL, little is known about the dimensions that constitute high QWL among academics. Therefore, this study aimed at contributing to the literature by conducting a detailed validation of seven dimensions of QWL through the Exploratory Factor Analysis (EFA) procedure.
\end{abstract}

Methodology: This study employed a cross-sectional research design to establish reliable measures for the QWL construct. The items were adapted and modified to suit this study. Study data was obtained using a structured questionnaire from 100 randomly selected academics from the five Malaysian research universities. The study further conducted the Exploratory Factor Analysis (EFA) procedure using IBM-SPSS version 21.0.

Main Findings: A total of 51 items were initially developed to measure QWL construct, however, from the EFA procedure, the study found that 8 items with factor loading below the cut-off point of .60 were deleted and 48 items with a factor loading above the cut-off point of .60 were retained and deemed suitable to measure the QWL construct.

Applications of this study: This study validated the dimensions that lead to improved QWL. Therefore, this study is particularly useful to the Malaysian universities' management who aim to obtain benefits from super motivated and highperformance academics by making sure that the workers' overall well-being is protected in the workplace.

Novelty/Originality of this study: This study established a validated and reliable instrument for measuring the QWL construct among academics in the Malaysian research universities.

Keywords: Quality of Work Life (QWL), Academics, Malaysian Research Universities, Exploratory Factor Analysis (EFA), Reliability Analysis.

\section{INTRODUCTION}

In a knowledge-centered economy, the job of the university is not just limited to the dispersion of knowledge through educating but, significantly, to the production of new knowledge and development of the existing knowledge base through research activities, along with the promotion and dispersion of knowledge to society through service and teaching (Wan et al., 2015). The competition among higher education institutions (HEIs) globally to be recorded in world-class ranking universities has changed Malaysian HEIs by intensifying research and innovation; whereas uplifting the country's knowledge-intensive economy (Ramli et al., 2013; Shariffuddin et al., 2017). Research universities (RUs) worldwide have become more central to their societies primarily because they represent the central knowledge resources in the societies (Sheriff \& Abdullah, 2017; Yazit \& Zainab, 2007).

The academics are strategic resources in any higher education institution, and the ability of universities to accomplish the task expected by the society depends on extremely motivated employees (Aslan et al., 2014). According to Leitão et al. (2019), in order to maintain high productivity and keep the employees motivated, the employer must improve the employees' perceived quality of work life (QWL). Daud et al. (2015) noted that understanding the QWL and its connection with organizational commitment (OC) would improve the degree of commitment among academics and motivate them to produce various high impact research papers. The HEIs will continue to produce excellent graduates at the same time. QWL is a multidimensional construct that incorporates a worker's sentiments about different components of their work including the job design, job stress, job security, pay and reward systems, organizational support, involvement in decision-making, work environment, work-related health and safety, training and career development opportunities, and the balance between personal life and job affairs (Adhikari \& Gautam, 2010; Almarshad et al., 2019; Devin \& Farbod, 2016; Mejbel et al., 2013).

The organization and job designs can amount a substantial influence on employees. It is, therefore, imperative to understand the factors that impact the perceived QWL of the workers. An improved QWL is critical for establishments to remain 
attractive to the employees and enjoy continuous employment from the high performing ones in the organization (Vadivel \& Velmurugan, 2017). The improvement of QWL at the workplace is a concept that has captured the interest of employers and employees equally. Several scholars have explored the concept of QWL and identified the determining factors (dimensions) at the workplace (Almarshad, 2015; Huda, 2017; Kwahar \& Iyortsuun, 2018; Sojka, 2014; Waghmare \& Dhole, 2017). Given these perspectives of QWL by these researchers, it is essential to pose this question, what amounts to a high QWL? A study of these dimensions of QWL is of great importance since a direct correlation between the quality of work life and motivation, satisfaction, and productivity has been confirmed by previous studies (Leitão et al., 2019; Ramawickrama et al., 2018).

Some research works have been carried out to determine measures of QWL among academics in Malaysia (Daud et al., 2015; Khairunneezam et al., 2017; Mohammadi \& Karupiah, 2019; Rahman et al., 2019). Despite all the previous studies, there is still a lack of extensive research on some of the QWL dimensions such as social support, job security, and physical work environment (Daud, 2010; Farid et al., 2015). Therefore, this study aims at contributing to literature by conducting an in-depth validation of these seven QWL dimensions; job stress, job security, fair compensation, career development, worklife balance, physical work environment and perceived organizational support through exploratory factor analysis (EFA) procedure to help in reducing the ever-emerging debates in determining the appropriate dimensions to measure QWL construct among academics in the Malaysian research universities.

\section{LITERATURE REVIEW}

\section{Quality of work life (QWL)}

The concept quality of work life (QWL) was at first presented in the late 1960s as a method for concentrating on the impacts of employee encounters (Bowditch \& Buono, 2015). The observation of workers' perceptions about the quality of their worklife helps the employers get an awareness of where improvements can be made for better performance (Mejbel et al., 2013). In organizations, QWL is critical for the efficient and smooth running of organizations, because with having QWL commitment and loyalty of employees created, their optimal potential can be developed and utilized (Beloor et al., 2017). QWL is a complex and complicated construct that each dimension is being built on a different base; therefore, there is no agreement about the precise definition of QWL since it is a dynamic construct that developed with the growth of management. Thus, QWL can be seen as a broad management of various factors such as physical, social, psychological, and technological aspects that affect the organizational environment and its culture (Al-Shawabkeh \& Hijjawi, 2018).

Serey (2006) defined QWL as a chance to practice one's abilities and limits to confront difficulties and circumstances that require autonomy, initiative, and self-motivation. Rethinam and Ismail (2008) defined QWL as the efficiency of the workplace that supports improved well-being, job stability, career satisfaction, skill improvement, and balance among work and non-work life of workers. QWL has likewise been connected to improved job restructure, flexible work arrangements, career development, and work security (Reddy \& Reddy, 2013).

According to Rahman et al. (2017), QWL is considered as a concept that influences all issues in the organizational existence of workers that shapes the procedure of their continued employment and job satisfaction. Rekhi and Sharma (2018) mentioned the following dimensions of the QWL; fair and adequate compensation, healthy and safe working environment, chances for individual growth and development, the fulfillment of social needs at work, harmony among work and non-work undertakings, protection of employee privileges and the social significance of work life. Almarshad (2015) identified job stress, job occupied, work satisfaction, and working conditions as the underlying dimensions of quality of work life. According to Kwahar and Iyortsuun (2018) study, compensation and benefits, job satisfaction and job security, training and individual autonomy, work-life balance, safe and healthy work environment were found as the QWL dimensions most considered by employees in the Nigerian hotel industry.

\section{Dimensions of Quality of work life (QWL)}

The above discussions on the explanations and dimensions of QWL show that QWL is a multidimensional construct, which consists of various interconnected components such as job stress, job security, fair compensation, career development, worklife balance, physical work environment, and perceived organizational support. When all these identified factors are managed properly, they help individuals actualize their full potentials at the workplace.

\section{Job Stress}

Baqutayan (2015) described stress as the reaction of a person to the outcomes of the extreme environmental conditions that amount undue mental, behavioral and physiological burdens on that person. Stress includes how an individual reacts to outside pressures. Job stress is a result of the condition of a work environment that poses a danger to an employee (Muda et al., 2014). According to (Gharib et al. 2016), job stress is customarily experienced when the imbalance between requirements of the workplace and the people's capabilities increases, therefore at work, stress might be an awareness shown 
by conflict, ambiguity, and burden emerging from the workplace and the characteristics of the person. Some establishments may require the staff to accomplish a certain level of work, while their workers may lack the ability to cope with the given tasks. It is thus believed that the demand exceeds the capability of an individual, which concurrently fails to fulfill the expected outcome. Additionally, job stress has been recognized collectively as a social problem that has a combination of aspects that disrupt the employees physically and psychologically and affects their overall welfare (Bhui et al., 2016).

\section{Job Security}

Job security is described as workers' validation or confidence that they will remain employed by the same employer in the future (Artz \& Kaya, 2014). It refers to the sense of security, or a sort of feeling wherein a person's needs and wants are fulfilled (Mosaybian \& Jafari, 2017). The feeling of security is determined by the ability of individuals to protect what they have with the assurance of making earnings in the future (Daud, 2017). Job security can be defined as security against employment loss (Kraja, 2015). It is concerned with the state of realizing that one's employment is secure, with no likelihood of being terminated or made jobless (Sanyal et al., 2018). Jobs which are not supported by unlimited contract or lack the assurance for reasonable duration are considered to be insecure (Lucky et al., 2013). Employee job security is one of the critical components that aids employees' attachment with the employer (Ahmed et al., 2017).

\section{Fair Compensation}

Compensation is the duty of an organization to appreciate its workers for their accomplishment of the assigned task (Darma \& Supriyanto, 2017). Compensation refers to all the available tangible and intangible remunerations an employee receives from the employer as part of the employment affiliation (Muguongo et al., 2015). According to Dessler (2013), employee compensation includes all methods of reimbursement or rewards going to workers and arising from their employment, and it may be direct financial or indirect financial payments. Compensation is the "glue" that holds the worker and the establishment together, and it is prepared in the form of a mutually mandatory legal document specifying the amount to be paid to the worker and the contents of the package (Yamoah, 2014). Compensation includes expenses such as profit sharing, bonuses, overtime, and rewards that include financial and non-financial payments (Gupta \& Shaw, 2014; Mabaso \& Dlamini, 2017). The compensation procedure is vital and a foundation of dispute in most establishments. It is concerned with how people are rewarded based on their contributions to the organization (Christopher, 2019; Njoroge \& Kwasira, 2015).

\section{Career Development}

Omotayo et al. (2014) defined career as a series of positions a person is employed in all through his/her lifetime. Career is the continuous improvement, involvement, and skill attainment of an individual in a specific job role (Dialoke \& Nkechi, 2017). Career development is the lifetime procedure of managing learning, transitions, work, and leisure to be able to attain an individually determined and progressing ideal future (Armstrong, 2009). Career development is defined as "an ongoing, formalized effort by an organization that focuses on developing and enriching the organization's human resources in light of both the employees' and the organization's needs" (Kaya \& Ceylan, 2014). An organization's support is vital in any successful career development program. The organization that shows consideration to career development planning is at an improved position to gain high productivity from adequately trained, experienced, and talented employees (Gyansah \& Guantai, 2018). Career development covers a worker's professional life; it begins with employees' orientation, on-demand training, specialized courses, and diplomas or postgraduate studies (Salah, 2016). Employee development is the basis on which the self-confidence and competence of an individual employee are established (Robbins \& Judge, 2013). A successful employee development program aids to maintain a steady workforce and improve their morale (Ababneh, 2013; Khan et al., 2015).

\section{Work-life balance (WLB)}

Work-life balance (WLB) is defined as establishing cooperation by building an amicable connection between 'job' (career and ambition) and 'personal life' (family, health, leisure, pleasure, and spiritual aspects) (Nayak \& Sahoo, 2015). Work-life balance is in light of people's subjective assessments of harmony among their job and different aspects of their lives (Brough et al., 2014). Agha et al. (2017) described work-life balance as the way a person strives for a suitable equilibrium between the facet of work and life. Wong et al. (2017) noted that work-life balance is divided into three dimensions, for example, time balance (equal time dedicated to job and family tasks), participation balance (the same psychological participation in job and family duties), and satisfaction equilibrium (equal satisfaction derived from work and family responsibilities). Workers must make an effort to modify their job and non-job responsibilities, consequently to avoid role conflict and improve life satisfaction and job commitment (Omar et al., 2015). On the other hand, organizations need to make extra efforts to provide workers with an adequate support system in the workplace and life because they are often overburdened with workload (Chung, 2018). 


\section{Physical Work Environment}

Oludeyi (2015) defined the work environment in its purest form as the settings, circumstances, and conditions under which individuals work. The work environment was further explained by Briner (2000) as a very comprehensive classification that comprises the physical background (e.g., equipment and heat), job design (e.g., task complexity and work capacity), broader organizational characteristics (e.g., culture and history) and even features of the added organizational setting (e.g., workhome affairs, local labor market situations, and industry sector) (as cited in Nzewi et al., 2017). Therefore, the work environment is the entirety of the interrelationship that exists among the workers, the organizations, and the environment in which the workers carry out their duties. It also comprises of the human, the technical, and the organizational environment. Consequently, most workers spend 50\% of their lives in the workplace, which impacts the way they reason, understand, behave, communicate with colleagues and connect to their works (Chandrasekar, 2011; Hameed \& Amjad, 2009). Sehgal (2012), and Sultan et al. (2016) explained that the consideration for an improved physical workplace environment is on the idea that comfortable individuals are far more motivated and productive.

\section{Perceived Organizational Support (POS)}

Perceived organizational support (POS) has stirred much attention among scholars in the studies of management and psychology (Allen et al., 2008; Aube et al., 2007; Claudia, 2018; Herachwati et al., 2018; Kurtessis et al., 2015; Zhong et al., 2015). Based on organizational support theory (OST) (Eisenberger et al., 1986; Eisenberger \& Stinglhamber, 2011; Krishhan \& Mary, 2012), workers build up a standard view concerning the degree to which the employer appreciates their commitments and genuinely concerned about their welfare. In the literature, POS has been defined in different ways. POS is also defined as "how much the organization values employees' contributions and cares about them" (Allen et al., 2008). Employees also recognize organizational support because of how they humanize the organization (Burns, 2016). A study detailed that employees' views of organizational support will intensify or decline based on how they attribute humanlike features to the company (Caesens et al., 2017).

\section{RESEARCH METHODOLOGY}

The methodology employed is crucial in achieving the aim of any study. This study employed a cross-sectional research design to establish reliable measures for the quality of work life (QWL) construct among academics in the Malaysian research universities. The approach for this study is quantitative, and data was obtained using a self-administered questionnaire. A detailed literature review was carried out to identify items measuring the QWL construct. The items were adapted and modified to suit this study. A total of 100 academics from the five Malaysian research universities were randomly selected and given the self-administered questionnaire for data collection. The Exploratory Factor Analysis (EFA) procedure using IBM-SPSS version 21.0 was carried out.

\section{Research Instrument}

In order to obtain data for establishing the appropriate measures of quality of work life (QWL) among Malaysian academics, a structured questionnaire was prepared with 51 items on a 10-point interval scale ranging from $1=$ strongly disagree to $10=$ strongly agree. Job stress was measured using a 13-item measure established by Parker and Decotiis (1983), which covers organizational and job-related stress. A sample item is "I have too much work and too little time to do it." Job security was assessed using a 7-item measure established by Lahey and Kuhnert (1988). A sample item is "I can be sure of my present job as long as I do good work." Fair compensation was assessed using a 10-item measure adapted from Williams et al. (2002) and Folger and Konovsky (1989). A sample item is "I currently receive much more benefits compared with others working for this university." Career development was measured using a 6-item measure adapted from Kim (2015). A sample item is "I make an effort to engage in the greater professional community." The physical work environment was assessed using a 7item measure adapted from NLSA (2007) and FLoV (2017). A sample item is "I am aware of the risks and hazards of my work environment." Work-life balance was measured using a 4-item scale developed by Brough et al. (2014). A sample item is "I currently have a good balance between the time I spend at work and the time I have available for non-work activities." Perceived organizational support was measured using a 4-item measure adapted from Eisenberger et al. (1986). A sample item is "The organization values my contribution to its well-being."

\section{EXPLORATORY FACTOR ANALYSIS (EFA)}

The researcher adapted the measuring instrument for QWL construct from previous literature and modified the items to suit the current study. According to Bahkia et al. (2019, 2020), Hoque et al. (2018), Rahlin et al. (2019), and Shkeer \& Awang (2019), pre-test and pilot-test must be conducted to validate the modified instrument, mainly if the original instrument was developed in the population of different culture and industry from the present study. Once the modification process was concluded, the questionnaire was reviewed by two experts; a senior lecturer and a professor for content validity and face validity as a pre-test for this questionnaire to ensure that the measures are suitable for the intended purpose and understandable. The criterion validity was determined by the professor, who is a statistician and confirmed that the scales 
used to measure data are suitable for the statistical analysis. The experts made some relevant comments for some of the questions to be shortened and reworded to avoid double-barreled questions. The questionnaire was reviewed accordingly and revised based on the suggestions of the experts and the researcher further pre-tested the questionnaire to 30 academics in a research university, they were asked to put down their comments on the clarity and relevance of the questionnaire to their jobs, and evaluate the uniformity in their responses.

After all the necessary adjustments according to pre-test results have been completed, the researcher distributed the questionnaire to the respondents to obtain data of a minimum of 100 responses for the exploratory factor analysis (EFA) (Hair et al., 2010; Rahlin et al., 2020; Baistaman et al., 2020, 2020a). Hair et al. (2014, p.92) stated that "factor analysis is an interdependence technique whose primary objective is to define the underlying structure among the variables in the analysis." The factors are latent constructs that cannot be measured directly; instead, they represent a group of the items for their measurements. EFA procedure is employed when there is ambiguity about the number of factors that may exist in a set of variables (Nayak, 2016). The primary purpose of this procedure is, to sum up the data enclosed in a large number of the initial items into a smaller set of new factors with the smallest loss of details (Baistaman et al., 2020, 2020a; Hair et al., 2014, p.94; Hoque et al., 2018; Mahfouz et al.,2019; Rahlin et al., 2020a).

\section{RESULTS}

\section{The Exploratory Factor Analysis (EFA) for Quality of Work Life (QWL) construct}

The quality of work life construct consists of 51 items in a questionnaire. The 10-point interval scale was supported by Awang et al. (2016), who state that 10 points scale is more accurate when compared to 5 points scale in the measurement model because of more extensive choice and more independence. The items are coded as Q1 to Q51 (Table 1). The results in Table 1 show the descriptive statistics for each item measuring the QWL construct. The mean value for every item ranged from 4.12 to 8.31 , while the standard deviation of the value ranged from 1.719 to 3.036.

Table 1: The Descriptive Statistics for items measuring QWL Construct

\begin{tabular}{|c|c|c|c|}
\hline \multicolumn{3}{|c|}{ Descriptive Statistics } & \multirow[b]{2}{*}{ Std. Deviation } \\
\hline Item & Statement & Mean & \\
\hline \multicolumn{4}{|c|}{ Job Stress } \\
\hline Q1 & I have felt nervous as a result of my job & 5.59 & 2.864 \\
\hline Q2 & Working here makes it hard to spend enough time with my family & 5.05 & 2.532 \\
\hline Q3 & My job gets to me more than it should & 5.46 & 2.483 \\
\hline Q4 & I spend so much time at work & 5.97 & 2.548 \\
\hline Q5 & Working here leaves little time for other activities & 5.54 & 2.564 \\
\hline Q6 & There are lots of times when my job drives me right up the wall & 5.16 & 2.619 \\
\hline Q7 & Sometimes when I think about my job I get a tight feeling in my chest & 4.21 & 2.618 \\
\hline Q8 & I frequently get the feeling I am married to my job & 4.36 & 2.757 \\
\hline Q9 & I have too little time to do all the work I have & 5.23 & 2.795 \\
\hline Q10 & I feel guilty when I take time off from a job & 5.32 & 2.729 \\
\hline Q11 & I feel like I never have a day off & 4.80 & 2.988 \\
\hline Q12 & $\begin{array}{l}\text { I sometimes fear the telephone ringing at home because the call might be job- } \\
\text { related }\end{array}$ & 4.12 & 2.675 \\
\hline Q13 & Too many people at my level in the university get burned out by job demands & 5.50 & 2.393 \\
\hline \multicolumn{4}{|c|}{ Job Security } \\
\hline Q14 & I can keep my job for as long as I want it & 7.27 & 2.581 \\
\hline Q15 & This job has retirement security & 8.13 & 2.389 \\
\hline Q16 & I am not really sure how long my job will last & 4.69 & 3.007 \\
\hline Q17 & There is a real need for my position in this university & 7.88 & 2.310 \\
\hline Q18 & If my particular job were phased out, the university would try hard to replace it & 6.44 & 2.738 \\
\hline Q19 & I can be sure of my job as long as I do good work & 8.03 & 2.422 \\
\hline
\end{tabular}




\begin{tabular}{|c|c|c|c|}
\hline Q20 & I am afraid of losing my job & 4.49 & 3.036 \\
\hline \multicolumn{4}{|c|}{ Fair Compensation } \\
\hline Q21 & $\begin{array}{l}\text { I currently receive much more benefits compared with others working for this } \\
\text { university }\end{array}$ & 6.54 & 2.076 \\
\hline Q22 & $\begin{array}{l}\text { Compared with others in my job category at this university, I receive much more } \\
\text { benefits }\end{array}$ & 6.19 & 2.177 \\
\hline Q23 & $\begin{array}{l}\text { Compared with others in my job category outside of this university, my current } \\
\text { benefits are much more }\end{array}$ & 6.41 & 2.628 \\
\hline Q24 & $\begin{array}{l}\text { Compared with others I know with similar abilities and training, my current } \\
\text { benefits are much more }\end{array}$ & 6.21 & 2.450 \\
\hline Q25 & Compared with others my age, my current benefits are much more & 6.17 & 2.578 \\
\hline Q26 & $\begin{array}{l}\text { Compared with others with my level of seniority, my current benefits are much } \\
\text { more }\end{array}$ & 5.90 & 2.480 \\
\hline Q27 & Compared to my friends and family, my current benefits are much more & 6.95 & 2.354 \\
\hline Q28 & $\begin{array}{l}\text { Compared with the benefits I need to meet my financial needs, my current } \\
\text { benefits are much more }\end{array}$ & 6.18 & 2.231 \\
\hline Q29 & The size of my last raise was very fair & 6.46 & 2.430 \\
\hline Q30 & $\begin{array}{l}\text { My most recent raise when compared to my expectations was much more than } \\
\text { expected }\end{array}$ & 6.03 & 2.226 \\
\hline \multicolumn{4}{|c|}{ Career Development } \\
\hline Q31 & I make an effort to engage in the greater professional community & 7.47 & 1.749 \\
\hline Q32 & I proactively modify my work approach in order to develop the best practice & 7.80 & 1.831 \\
\hline Q33 & My supervisor provides feedback on a regular basis to develop my expertise & 6.34 & 2.379 \\
\hline Q34 & I have frequent contact with more experienced people in the same field I work & 6.92 & 2.232 \\
\hline Q35 & My work involves multiple roles and responsibilities & 8.31 & 1.784 \\
\hline Q36 & I am closely guided by others with more expertise & 5.72 & 2.574 \\
\hline \multicolumn{4}{|c|}{ Physical Work Environment } \\
\hline Q37 & I am aware of the hazards of my work environment & 7.35 & 2.171 \\
\hline Q38 & My department is committed to ensuring the safety of its employees & 7.64 & 1.783 \\
\hline Q39 & I am aware of my role in protecting my personal safety in the workplace & 7.88 & 1.748 \\
\hline Q40 & My work premises are well suited for the work to be performed & 7.98 & 1.775 \\
\hline Q41 & The shared staff areas are clean & 7.46 & 2.007 \\
\hline Q42 & There is sufficient space at my workplace & 8.25 & 1.719 \\
\hline Q43 & There are no problems with being too hot or too cold at my workplace & 7.86 & 2.122 \\
\hline \multicolumn{4}{|c|}{ Work-Life Balance } \\
\hline Q44 & I currently have a good balance between my work and non-work activities & 7.06 & 2.223 \\
\hline Q45 & I have difficulty balancing my work and non-work activities & 4.53 & 2.683 \\
\hline Q46 & The balance between my work and non-work activities is just about right & 6.58 & 2.305 \\
\hline Q47 & Overall, I believe that my work and non-work life are balanced & 6.92 & 2.359 \\
\hline \multicolumn{4}{|c|}{ Perceived Organizational Support } \\
\hline Q48 & The university values my contribution to its well-being & 6.31 & 2.431 \\
\hline Q49 & The university strongly considers my goals and values & 6.39 & 2.481 \\
\hline Q50 & The university cares about my general satisfaction at work & 6.12 & 2.547 \\
\hline Q51 & The university takes pride in my accomplishments at work & 6.72 & 2.578 \\
\hline
\end{tabular}

The screen plot in Figure 1 shows that ten components surfaced from the EFA procedure for this construct. The EFA procedure grouped the 51 items into ten distinct components. Each component has a certain number of items. The rotated component matrix shows the items that are grouped under which component. 


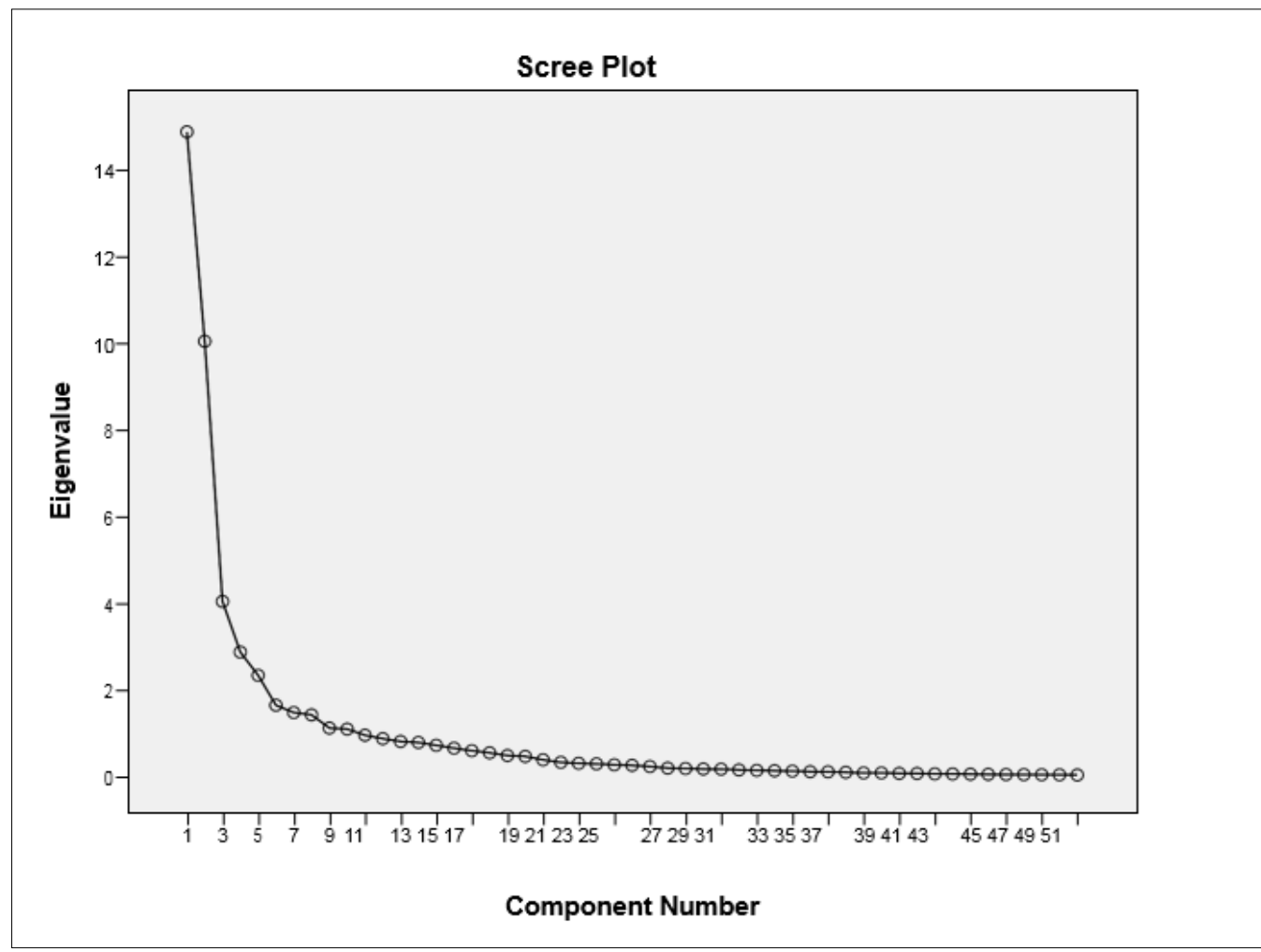

Figure 1: The Scree Plot for QWL Construct extracted four components

The EFA procedure using Principal Component Analysis (PCA) with Varimax Rotation was carried out on the 51 items assessing QWL construct. The results in Table 2 show that the Bartletts' Test of Sphericity is significant (P-Value $<.05)$. Additionally, the measure of sampling adequacy by Kaiser-Meyer-Olkin (KMO) (.741) is acceptable since it is above the minimum value of .60 (Awang, 2012; Bahkia et al., 2019, 2020; Rahlin et al., 2020a). These two results (Bartlett's Test is significant and $\mathrm{KMO}>.60$ ) indicate that the data is satisfactory to continue with the data reduction technique (Awang et al., 2015; Hoque et al., 2018; Shkeer \& Awang, 2019).

Table 2: The KMO and Bartlett's Test

\begin{tabular}{lll}
\hline \multicolumn{2}{l}{ KMO and Bartlett's test } & \\
\hline \multicolumn{2}{l}{ Kaiser-Meyer-Olkin Measure of Sampling Adequacy. } & .741 \\
\hline \multicolumn{1}{c}{ Bartlett's Test of Sphericity } & Approx. Chi-Square & 6100.206 \\
\hline Df & 1275 \\
\hline \hline Sig. & .000 \\
\hline
\end{tabular}

\section{The Components and Total Variance Explained}

The results in Table 3 shows there are ten components from the EFA procedure based on the Eigenvalue greater than 1.0. The eigenvalues ranged from 1.071 to 14.892 . While the variance explained for component 1 is $29.200 \%$, component 2 is $19.697 \%$, component 3 is $7.891 \%$, component 4 is 5.593, component 5 is 4.539 , component 6 is 3.183 , component 7 is 2.850 , component 8 is 2.745 , component 9 is 2.148 and component 10 is 2.099 . The total variance explained for measuring the QWL construct is $79.946 \%$, and has surpassed the minimum requirement of 60\% (Awang et al., 2015; Noor et al., 2015; Yahaya et al., 2018).

Table 3: The Components and Total Variance Explained for QWL Construct

\begin{tabular}{ccccccc}
\hline \multirow{2}{*}{ Component } & \multicolumn{2}{c}{ Initial Eigenvalues } & \multicolumn{2}{c}{ Extraction Sums of Squared Loadings } \\
\cline { 2 - 6 } & Total & $\begin{array}{c}\text { \% of } \\
\text { Variance }\end{array}$ & $\begin{array}{c}\text { Cumulative } \\
\text { \% }\end{array}$ & Total & $\begin{array}{c}\text { \% of } \\
\text { Variance }\end{array}$ & $\begin{array}{c}\text { Cumulative } \\
\text { \% }\end{array}$ \\
\hline 1 & 14.892 & 29.200 & 29.200 & 14.892 & 29.200 & 29.200 \\
\hline
\end{tabular}




\begin{tabular}{ccccccc}
\hline 2 & 10.045 & 19.697 & 48.897 & 10.045 & 19.697 & 48.897 \\
\hline 3 & 4.024 & 7.891 & 56.788 & 4.024 & 7.891 & 56.788 \\
\hline 4 & 2.853 & 5.593 & 62.382 & 2.853 & 5.593 & 62.382 \\
\hline 5 & 2.315 & 4.539 & 66.921 & 2.315 & 4.539 & 66.921 \\
\hline 6 & 1.623 & 3.183 & 70.104 & 1.623 & 3.183 & 70.104 \\
\hline 7 & 1.453 & 2.850 & 72.954 & 1.453 & 2.850 & 72.954 \\
\hline 8 & 1.400 & 2.745 & 75.699 & 1.400 & 2.745 & 75.699 \\
\hline 9 & 1.095 & 2.148 & 77.847 & 1.095 & 2.148 & 77.847 \\
\hline 10 & $\mathbf{1 . 0 7 1}$ & $\mathbf{2 . 0 9 9}$ & $\mathbf{7 9 . 9 4 6}$ & $\mathbf{1 . 0 7 1}$ & $\mathbf{2 . 0 9 9}$ & 79.946
\end{tabular}

Table 4 presents the ten components and respective items. The factor loading for each item except Q20, Q31, Q32, Q35, Q36, Q37, Q41, and Q43 is higher than .60. Accordingly, the eight items with factor loading less than .60 were deleted (Awang, 2014; Baistaman et al., 2020, 2020a; Yahaya et al., 2018). Therefore, forty-three (43) items will be retained and are suitable to assess the QWL construct. Furthermore, no item was assigned to component six (6) and ten (10) because the factor loading for items under these components was below the cut-off point of .60 .

Table 4: The ten components and their items

\begin{tabular}{|c|c|c|c|c|c|c|c|c|c|c|}
\hline \multicolumn{11}{|c|}{ Rotated Component Matrix } \\
\hline & \multicolumn{10}{|c|}{ Component } \\
\hline & 1 & 2 & 3 & 4 & 5 & 6 & 7 & 8 & 9 & 10 \\
\hline Q1 & & .638 & & & & & & & & \\
\hline Q2 & & .821 & & & & & & & & \\
\hline Q3 & & .852 & & & & & & & & \\
\hline Q4 & & .871 & & & & & & & & \\
\hline Q5 & & .780 & & & & & & & & \\
\hline Q6 & & .867 & & & & & & & & \\
\hline Q7 & & .795 & & & & & & & & \\
\hline Q8 & & .795 & & & & & & & & \\
\hline Q9 & & .863 & & & & & & & & \\
\hline Q10 & & .721 & & & & & & & & \\
\hline Q11 & & .892 & & & & & & & & \\
\hline Q12 & & .737 & & & & & & & & \\
\hline Q13 & & .718 & & & & & & & & \\
\hline Q14 & & & & & .772 & & & & & \\
\hline Q15 & & & & & .694 & & & & & \\
\hline Q16 & & & & & & & & & .818 & \\
\hline Q17 & & & & & & & 775 & & & \\
\hline Q18 & & & & & & & 831 & & & \\
\hline Q19 & & & & & .864 & & & & & \\
\hline \multicolumn{11}{|l|}{ Q20 Deleted Item } \\
\hline $\mathrm{Q} 21$ & .853 & & & & & & & & & \\
\hline Q22 & .842 & & & & & & & & & \\
\hline Q23 & .802 & & & & & & & & & \\
\hline Q24 & .914 & & & & & & & & & \\
\hline Q25 & .894 & & & & & & & & & \\
\hline Q26 & .878 & & & & & & & & & \\
\hline Q27 & .850 & & & & & & & & & \\
\hline Q28 & .779 & & & & & & & & & \\
\hline Q29 & & & & & & & & .663 & & \\
\hline Q30 & & & & & & & & .676 & & \\
\hline \multicolumn{11}{|l|}{ Q31 Deleted Item } \\
\hline \multicolumn{11}{|l|}{ Q32 Deleted Item } \\
\hline $\mathrm{Q} 33$ & .707 & & & & & & & & & \\
\hline
\end{tabular}




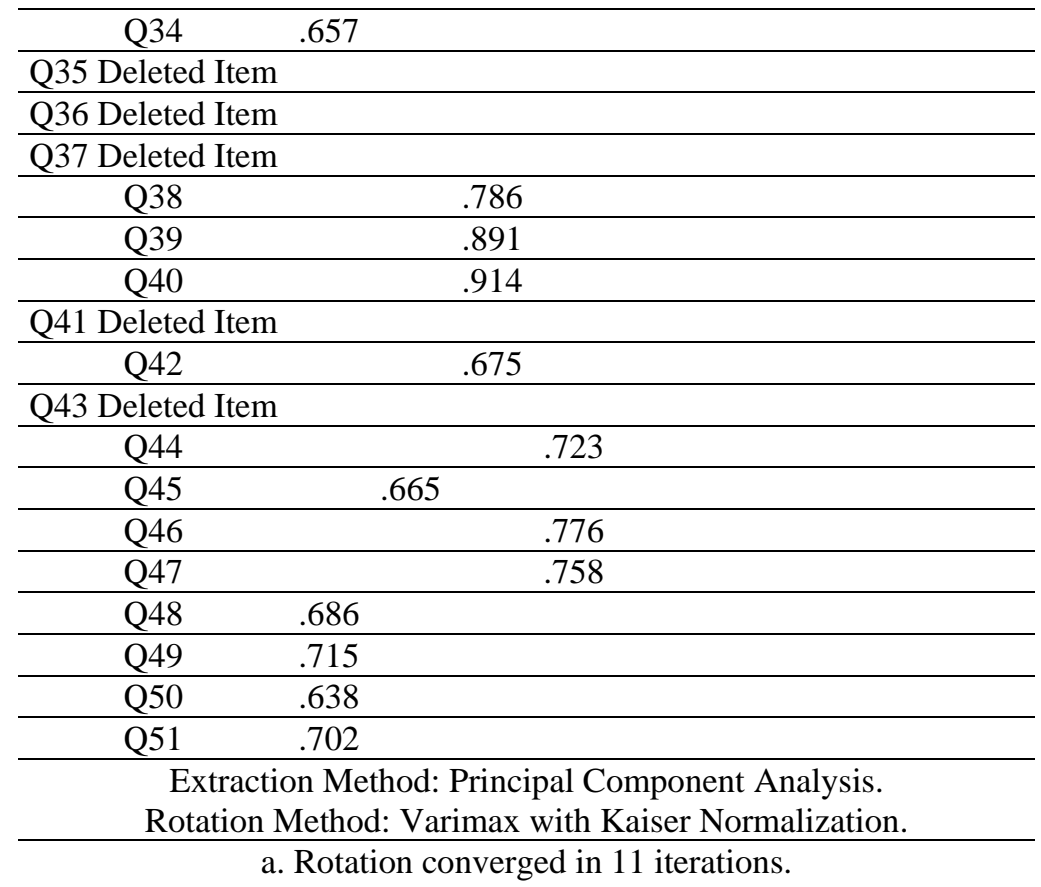

\section{The Internal Reliability for the Instrument Measuring QWL Construct}

The final test is to determine the value of Cronbach's Alpha for every component to evaluate the internal reliability of each component measuring the QWL construct. The internal reliability assesses the consistency of results across items measuring the same construct. The value of Cronbach's Alpha should be greater than .7 for the items to achieve high internal reliability (Rovai et al., 2014).

Table 5: The Reliability Analysis for every component measuring QWL Construct

\begin{tabular}{llll}
\hline & Name of Component & No of items & Cronbach's Alpha \\
\hline 1 & Component 1 & 14 & .965 \\
\hline 2 & Component 2 & 14 & .956 \\
\hline 3 & Component 3 & 4 & .904 \\
\hline 4 & Component 4 & 3 & .957 \\
\hline 5 & Component 5 & 3 & .878 \\
\hline 6 & Component 6 & 0 & - \\
\hline 7 & Component 7 & 2 & .750 \\
\hline 8 & Component 8 & 2 & .912 \\
\hline 9 & Component 9 & 1 & - \\
\hline 10 & Component 10 & 0 & - \\
\hline
\end{tabular}

The Cronbach's Alpha for the ten components assessing the QWL construct, as presented in Table 5, ranged from .750 to .965. Therefore, the items in all seven components analyzed have attained the acceptable internal reliability since their Cronbach's values are higher than .7. However, component nine (9) internal reliability (Cronbach's Alpha) could not be determined because of the limitation of having only one item. Additionally, no item was assigned to component six (6) and ten (10) because the factor loading for items under these components was below the cut-off point of .60; consequently, their Cronbach's Alpha could not also be determined.

\section{DISCUSSION}

The purpose of this study was to conduct a detailed validation of seven dimensions of quality of work life (QWL) among academics through exploratory factor analysis (EFA) procedure. According to the EFA results, ten components structure of the QWL instrument explained 79.946\% of the variance in the configuration of associations among the items. Seven out of the ten components had high reliabilities (Cronbach's $\alpha$ ranged between .750 and .965). Component nine (9) internal reliability (Cronbach's Alpha) could not be determined because of the limitation of having only one item. Furthermore, no item was assigned to component six (6) and ten (10) due to low factor loading below the acceptable cut-off point of .6 for 
this study; therefore, their Cronbach's Alpha could not also be assessed. Forty-three items remained in the final questionnaire after eight items were deleted which were cross-loaded on multiple components with factor loading below .60 (component 1: 14 items; component 2: 14 items; component 3: 4 items; component 4: 3 items; component 5: 3 items; component 6: 0 item; component 7: 2 items; component 8: 2 items; component 9: 1 item; and component 10: 0 item). Accordingly, the ten components structure of the QWL instrument has been established in this study.

It was further established that the data used in this study were suitable for conducting a valid EFA based on descriptive statistical analysis. The sample size of 100 academics was adequate for the EFA (Bahkia et al., 2019, 2020; Hair et al., 2010; Rahlin et al., 2019, 2020; Shkeer \& Awang, 2019). Based on the results of the EFA, this study achieved a modest milestone with a structure of ten dimensions by deleting eight items that were cross-loaded in multiple dimensions with a factor loading below the defined threshold in this study.

This study examined the validity of the instrument during the initial stage of the instrument development process, using the qualified recommendations from two experts and thirty academics carefully. According to the results of the EFA in this study, academics, higher education management, or human resource administrators can use this QWL instrument in order to determine the workplace factors that constitute a high level of QWL for improved performance and commitment among the academics by measuring the identified factors in this study. Moreover, when academics come to recognize what factors aid their ability to perform and commit to a particular organization, the instrument may offer them a chance to enhance their enthusiasm towards carrying out their assigned duties. Nevertheless, more studies are needed to determine the existing relationships between the latent variables by carrying out a confirmatory factor analysis (CFA), as suggested by $\underline{\mathrm{Yu}}$ and Richardson (2015).

\section{CONCLUSION}

The dimensions of quality of work life (QWL) identified in this study are job stress, job security, fair compensation, career development, work-life balance, physical work environment, and perceived organizational support. The results from the exploratory factor analysis (EFA) disclosed that the measurement items from the seven dimensions adapted from the literature were grouped into ten components; however, the items with the acceptable factor loading of above .60 only loaded into eight components, components six and ten were empty with no recorded item that met the minimum factor loading requirement for the study. The results also showed that the construct could adequately be measured using forty-three items with the total explained variance above 60\%. The Kaiser-Meyer-Olkin (KMO) value of .741 (> .60) also shows that the data is adequate for use in this study. Additionally, the items in all measurable components assessing the construct possess excellent internal reliability since all Cronbach's values have surpassed the acceptable range of .7. The detailed measurement development and validation processes of the current study have confirmed that the new QWL instrument is internally consistent and reliable. Therefore, this current study contributes to the QWL literature by identifying the dimensions that contribute to high QWL among academics in the Malaysian research universities. This study also contributed by establishing a validated and reliable instrument for measuring the QWL construct.

\section{LIMITATION AND STUDY FORWARD}

Firstly, a significant issue that was beyond our control during the process of data collection was respondents' bias, which could be as a result of their unwillingness to respond to the questionnaire or their busy schedules. Another limitation of this study was that it focused mainly on Malaysian research universities and utilized data from only 100 randomly selected academics. This drawback can be addressed in future studies by considering other Malaysian public universities and involving more samples to ascertain if the same identified and validated measures of quality of work life (QWL) in this study will be the same in other universities. Thirdly, this study employed a cross-sectional research design that involved the only one-time collection of data within a short period. However, further studies could look into a more long-term study of the identified measures of QWL to fully understand how they improve over time and their influence on the academics' motivation, commitment, and performance.

\section{ACKNOWLEDGMENT}

The authors would like to thank Universiti Sultan Zainal Abidin (UniSZA) for providing the needed funds for this study. The authors also would like to thank the academics in the five Malaysian research universities for their corporation during the data collection.

\section{AUTHORS' CONTRIBUTION}

Amauche Ehido: Conceptualization, Methodology, Formal analysis, Writing - Original Draft, Project administration.

Zainudin Awang: Supervision, Statistical Analysis, Validation, Resources, Writing - Review \& Editing.

Bahyah Abdul Halim: Supervision, Project Administration. 
Chukwuebuka Ibeabuchi: Investigation, Data Collection, Data management, Writing - Review \& Editing.

\section{REFERENCES}

1. Adhikari, R. D., \& Gautam, D. (2010). Labor legislations for improving quality of work life in Nepal. International Journal of Law and Management, 52(1), 40-53. https://doi.org/10.1108/17542431011018534

2. Agha, K., Azmi, F. T., \& Irfan, A. (2017). Work-Life balance and job satisfaction: An empirical study focusing on higher education teachers in Oman. International Journal of Social Science and Humanity, 7(3), 164-171. https://doi.org/10.18178/ijssh.2017.V7.813

3. Ahmed, S., Haderi, S. M. S. A., Ahmad, F. B., Jaaffar, A. R. B., Walter, J., \& Al-Douis, G. A. A. (2017). Employee job security and performance relationship in developing economy through employee engagement: Critical analysis with PLS-SEM. International Journal of Economic Research, 14(19), 133-147.

4. Ababneh, R. (2013). Antecedents and outcomes of career development in Jordanian public sector. Journal of Emerging Trends in Economics and Management Sciences, 4(4), 417- 426.

5. Allen, M. W., Armstrong, D. J., Reid, M. F., \& Riemenschneider, C. K. (2008).Factors impacting the perceived organizational support of IT employees. Information \& Management, 45(8), $\quad$ 556-563.

ttps://doi.org/10.1016/j.im.2008.09.003

6. Almarshad, S. O. (2015). A measurement scale for evaluating quality of work life: conceptualization and empirical validation. Trends in Applied Sciences Research, 10, 143-156. https://doi.org/10.3923/tasr.2015.143.156

7. Almarshad, S., Toukabri, M., \& Yillah, M. S. (2019). Quality of work life as a determinant of social responsibility in the public sector: The case of the governmental sector of the northern borders region in Saudi Arabia. European Journal of Sustainable Development, 8(1). https://doi.org/10.14207/ejsd.2019.v8n1p82

8. Al-Shawabkeh, K. M., \& Hijjawi, G. S. (2018). Impact of quality of work-life (QWL) on organizational performance: An empirical study in the private Jordanian universities. Asian Social Science, 14(6), 145. https://doi.org/10.5539/ass.v14n6p145

9. Armstrong, M. (2009). Armstrongs handbook of human resource management practice a guide to managing for results. Kogan Page.

10. Artz, B., \& Kaya, I. (2014). The impact of job security on job satisfaction in economic contractions versus expansions. Applied Economics, 46(24), 2873-2890. https://doi.org/10.1080/00036846.2014.914148

11. Aslan, A. S., Shaukata, S. Z., Ahmeda, I., Shaha, I. M., \& Mahfa, M. (2014). Job satisfactions of academics in Malaysian Public Universities. Procedia - Social and Behavioral Sciences, 114.154-158. https://doi.org/10.1016/j.sbspro.2013.12.676

12. Aube, C., Rousseau, V. M., \& Estelle, M. (2007). Perceived organizational support and organizational commitment: The moderating effect of locus of control and work autonomy. Journal of Managerial Psychology, 22(5), 479-495. https://doi.org/10.1108/02683940710757209

13. Awang, Z. (2012). Research methodology and data analysis. Penerbit Universiti Teknologi MARA Press.

14. Awang, Z. (2014). A Handbook on SEM for Academicians and Practitioners: The Step by Step Practical Guides for the Beginners. MPWS Rich Resource.

15. Awang, Z., Afthanorhan, W. M. A., Asri, M. A. M. (2015). Parametric and non-parametric approach in structural equation modeling (SEM): The application of bootstrapping. Modern Applied Science, 9(9), 58-67. https://doi.org/10.5539/mas.v9n9p58

16. Awang, Z., Afthanorhan, A., Mamat, M. (2016). The Likert scale analysis using parametric based structural equation modeling (SEM). Computational Methods in Social Sciences (CMSS), 4(1), 13-21.

17. Baistaman, J., Awang, Z., Nawawi, R., Arifin, N., Mustapha, W.M., and Shari, A.S. (2020). Assessing Measurement Model of Malaysian Voluntary Saving Decision for Future Retirement Planning using Confirmatory Factor Analysis. International Journal of Accounting, Finance and Business (IJAFB). 5 (26), 1-7.

18. Baistaman, J., Awang, Z., Afthanorhan, A., and Abdul Rahim, M.Z. (2020a). Developing and Validating the Measurement Model for Financial Literacy Construct using Confirmatory Factor Analysis. Humanities and Social Science Review. 8(2), 2020, 413-422. https://doi.org/10.18510/hssr.2020.8247

19. Bahkia, A. S., Awang, Z., Afthanorhan, A., Ghazali, P. L., \& Foziah, H. (2019). Exploratory factor analysis on occupational stress in context of Malaysian sewerage operations. The $4^{\text {th }}$ Innovation and Analytics Conference \& Exhibition (Iace 2019). https://doi.org/10.1063/1.5121111

20. Bahkia, A.S., Awang, Z., Rahlin. N.A., Zulkifli, A.R. (2020). The Importance of Supportive Leadership in the Sewerage Operation Industry: A case of Indahwater Konsortium Private IWK). Humanities \& Social Science Reviews, 8(3), 2020, 149-162. https://doi.org/10.18510/hssr.2020.8317

21. Baqutayan, S. M. S. (2015). Stress and coping mechanisms: A historical overview. Mediterranean Journal of Social Sciences, 6(2). https://doi.org/10.5901/mjss.2015.v6n2s1p479 
22. Beloor, V., Nanjundeswaraswamy, T. S., \& Swamy, D. R. (2017). Employee commitment and quality of work life A literature review. The International Journal of Indian Psychology, 4(2), 176-188.

23. Bhui, K., Dinos, S., Galant-Miecznikowska, M., Jongh, B. D., \& Stansfeld, S. (2016). Perceptions of work stress causes and effective interventions in employees working in public, private and non-governmental organisations: a qualitative study. BJPsych Bulletin, 40(6), 318-325. https://doi.org/10.1192/pb.bp.115.050823

24. Bowditch, J. L., \& Buono, A. F. (2015). A primer on organizational behavior. John Wiley \& Sons.

25. Briner, R. B. (2000). Relationships between Work Environments, Psychological Environments and Psychological Well-being. Occupational Medicine, 50(5), 299-303. https://doi.org/10.1093/occmed/50.5.299

26. Brough, P., Timms, C., O'Driscoll, M. P., Kalliath, T., Siu, O. L., Sit, C., \& Lo, D. (2014). Work-life balance: A longitudinal evaluation of a new measure across Australia and New Zealand workers. The International Journal of Human Resource Management, 25(19), 2724-2744. https://doi.org/10.1080/09585192.2014.899262

27. Burns, K. L. (2016). Perceived organizational support and perceived supervisor support as antecedents of work engagement [Master's thesis, San Jose State University]. SJSU Scholar Works. https://doi.org/10.31979/etd.8hf7$\underline{\mathrm{dh} 9 \mathrm{p}}$

28. Caesens, G., Stinglhamber, F., Demoulin, S., \& Wilde, M. D. (2017). Perceived organizational support and employees' well-being: the mediating role of organizational dehumanization. European Journal of Work and Organizational Psychology, 26(4), 527-540. https://doi.org/10.1080/1359432X.2017.1319817

29. Chandrasekar, K. (2011). Workplace environment and its impact on organisational performance in public sector. International Journal of Enterprise Computing and Business Systems, 1(1), 1-16.

30. Christopher, N. (2019). The effectiveness of HRM policies and practices. International journal of social sciences, 2(1), 24-32. https://doi.org/10.31295/ijss.v2n1.51

31. Chung, H. (2018). Women's work penalty in access to flexible working arrangements across Europe. European Journal of Industrial Relations, 25(1), 1-18. https://doi.org/10.1177/0959680117752829

32. Claudia, M. (2018). The influence of perceived organizational support, job satisfaction and organizational commitment toward organizational citizenship behavior: A study of the permanent lecturers at university of Lambung Mangkurat, Banjarmasin. Journal of Indonesian Economy and Business, 33(1), 23-45. https://doi.org/10.22146/jieb.17761

33. Darma, P. S., \& Supriyanto, A. S. (2017). The effect of compensation on satisfaction and employee performance. Management and Economics Journal, 1(1), 69-78. https://doi.org/10.18860/mec-j.v1i1.4524

34. Daud, N. (2010). Investigating the relationship between the quality of work life and organizational commitment amongst employees in Malaysian firms. International Journal of Business and Management, 5(10), 75-82. https://doi.org/10.5539/ijbm.v5n10p75

35. Daud, N. (2017). Job security and well-being among private workers in Malaysia. Journal of Technology Management and Business, 4(1), 25-38.

36. Daud, N., Yaakob, Y., \& Ghazali, S. N. M. (2015). Quality of work life and organizational commitment: empirical investigation among academic in public institution of higher learning. IJABER, 13(7), 6129-6146. https://doi.org/10.1109/ICIMTR.2012.6236480

37. Dessler, G. (2013). Human Resource Management (13th ed.). Pearson.

38. Devin, H. F., \& Farbod, D. (2016). Relationships among work life, mental health status and organisation-based selfesteem. Proceedings of the Latvian Academy of Sciences. Section B. Natural, Exact, and Applied Sciences, 70(6), 365-369. https://doi.org/10.1515/prolas-2016-0054

39. Dialoke, I., \& Nkechi, P. A .J. (2017). Effects of career growth on employees' performance: a study of nonacademic staff of Micheal Okpara University of Agriculture, Umudike, Umuahia Abia-State, Nigeria. Singaporean Journal of Business Economics, and Management Studies, 5(7), 8-18. https://doi.org/10.12816/0037246

40. Eisenberger, R., Huntington, R., Hutchison, S., \& Sowa, D. (1986). Perceived organizational support. Journal of Applied Psychology, 71(3), 500-507. https://doi.org/10.1037/0021-9010.71.3.500

41. Eisenberger, R., \& Stinglhamber, F. (2011). Perceived organizational support: Fostering enthusiastic and productive employees. American Psychological Association. https://doi.org/10.1037/12318-000

42. Farid, H., Izadi, Z., Ismail, I. A., \& Alipour, F. (2015). Relationship between quality of work life and organizational commitment among lecturers in a Malaysian public research university. The Social Science Journal, 52(1), 54-61. https://doi.org/10.1016/j.soscij.2014.09.003

43. Folger, R., \& Konovsky, M. A. (1989). Effects of procedural and distributive justice on reactions to pay raise decisions. Academy of Management Journal, 32(1), 115-130. https://doi.org/10.2307/256422

44. Gharib, M., Jamil, S., Ahmed, M., \& Ghouse, S., (2016): The impact of job stress on job performance: A case study on academic staff at dhofar university. International Journal of Economic Research, 13(1), 21-33.

45. Gupta, N., \& Shaw, J. D. (2014). Employee compensation: The neglected area of HRM research. Human Resource Management Review, 24(1), 1-4. https://doi.org/10.1016/j.hrmr.2013.08.007 
46. Gyansah, S., \& Guantai K. H. (2018). Career development in organizations: Placing the organization and employee on the same pedestal to enhance maximum productivity. European Journal of Business and Management, 10(14), $40-42$.

47. Hair, J. F., Black, W. C., Babin, B. J., \& Anderson, R. E. (2010). Multivariate Data Analysis: A Global Perspective $\left(7^{\text {th }}\right.$ ed). Pearson Education.

48. Hair, J. F., Hult, G. T., Ringle, C., \& Sarstedt, M. (2014). A primer on partial least squares structural equation modeling (PLS-SEM). SAGE Publications. https://doi.org/10.1108/EBR-10-2013-0128

49. Hameed, A., \& Amjad, S. (2009). Impact of office design on employees' productivity: A case study of banking organizations of Abbottabad, Pakistan. Journal of Public Affairs, Administration and Management, 3(1), 1-13.

50. Herachwati, N., Sulistiawan, J., Alfirdaus, Z., \& Gonzales, M. B. N. (2018). The effects of perceived organizational support and social comparison on work attitudes. Problems and Perspectives in Management, 16(1), 12-21. https://doi.org/10.21511/ppm.16(1).2018.02

51. Hoque, A. S. M., Siddiqui, B. A., Awang, Z. B., \& Baharu, S. M. A. (2018). Exploratory factor analysis of entrepreneurial orientation in the context of Bangladesh small and medium enterprises (SMES). European Journal of Management and Marketing Studies, 3(2), 81-94.

52. Huda, K. N. (2017). Measuring the impacts of quality of work life indicators on the marketing representatives of pharmaceutical industries. Bangladesh Pharmaceutical Journal, 20(1), 46-53.

https://doi.org/10.3329/bpj.v20i1.32093

53. Institutionen för filosofi, lingvistik och vetenskapsteori (FLoV). (2017). Compilation of a working environment questionnaire and physical working environment inspection round 2017. The department of philosophy, linguistics and theory of science.

54. Kaya, C., \& Ceylan, B. (2014). An empirical study on the role of career development programs in organizations and organizational commitment on job satisfaction of employees. American Journal of Business and Management, 3(3), 178-191. https://doi.org/10.11634/216796061403551

55. Khairunneezam M., Suriani, O, S., \& Nadirah, A. H. N. (2017). Work-Life balance satisfaction among academics in public higher educational sector. International Journal of Academic Research in Business and Social Sciences, 7(13), 5-19. https://doi.org/10.6007/IJARBSS/v7-i13/3181

56. Khan, S. A., Rajasekar, J., \& Al-Asfour, A. (2015). Organizational career development practices: learning from an Omani company. International Journal of Business and Management, 10(9), 88-98. https://doi.org/10.5539/ijbm.v10n9p88

57. Kim, Y. (2015). Development of the employee expertise development scale (EEDS) [Doctoral dissertation, University of Connecticut]. Uconn Library. https://opencommons.uconn.edu/dissertations/989

58. Kraja, G. (2015). Job security and performance: Case study of the Albanian public administration. Academic Journal of Interdisciplinary Studies, 4(2), 19-26. https://doi.org/10.5901/ajis.2015.v4n2p19

59. Krishnan, J., \& Mary, V. S. (2012). Perceived organisational support-an overview on its antecedents and consequences. International Journal of Multidisciplinary Research, 2(4), 2-3.

60. Kurtessis, J. N., Eisenberger, R., Ford, M. T., Buffardi, L. C., Stewart, K. A., \& Adis, C. S. (2015). Perceived organizational support: A meta-analytic evaluation of organizational support theory. Journal of Management, 43(6), 1854-1884. https://doi.org/10.1177/0149206315575554

61. Kwahar, N., \& Iyortsuun, A. S. (2018). Determining the underlying dimensions of quality of work life (qwl) in the Nigerian hotel industry. Entrepreneurial Business and Economics Review, 6(1), 53-70. https://doi.org/10.15678/EBER.2018.060103

62. Lahey, M. A., \& Kuhnert, K.W. (1988). The meaning and measure of job security (Unpublished manuscript). University of Georgia, Washington.

63. Leitão, J., Pereira, D., \& Gonçalves, Â. (2019). Quality of work life and organizational performance: Workers' feelings of contributing, or not, to the organization's productivity. International Journal of Environmental Research and Public Health, 16(20), 3803. https://doi.org/10.3390/ijerph16203803

64. Lucky, E. O.-I., Minai, M. S., \& Rahman, H. A. (2013). Impact of job security on the organizational performance in a multiethnic environment. Research Journal of Business Management, 7(1), 64-70. https://doi.org/10.3923/rjbm.2013.64.70

65. Mabaso, C. M., \& Dlamini, B. I. (2017). Impact of compensation and benefits on job satisfaction. Research Journal of Business Management, 11(2), 80-90. https://doi.org/10.3923/rjbm.2017.80.90

66. Mahfouz, S., A., Awang, Z., \& Muda, H. (2019). The Impact of Transformational Leadership on Employee Commitment in the Construction Industry. International Journal of Innovation, Creativity and Change, 7(10).

67. Mejbel, A. A., Almsafir, M. K., Siron, R., \& Alnaser, A. S. M. (2013). The drivers of quality of working life (QWL): a critical review. Australian Journal of Basic and Applied Sciences, 7(10), 398-405. 
68. Mosaybian, N., \& Jafari, M. (2017). The study of relationship between job security and organizational commitment. Kuwait Chapter of Arabian Journal of Business and Management $\quad$ Review, $\quad 33(74), \quad 1-4$. https://doi.org/10.12816/0036703

69. Mohammadi, S., \& Karupiah, P. (2019). Quality of work life and academic staff performance: a comparative study in public and private universities in Malaysia. Studies in Higher Education,1-15. https://doi.org/10.1080/03075079.2019.1652808

70. Muda, I., Rafiki, A., \& Harahap, M. R. (2014). Factors influencing employees' performance: A study on the Islamic Banks in Indonesia. International Journal of Business and Social Sciences, 5(2), 73-80.

71. Muguongo, M. M., Muguna, A. T., \& Muriithi, D. K. (2015). Effects of compensation on job satisfaction among secondary school teachers in Maara sub - County of Tharaka Nithi County, Kenya. Journal of Human Resource Management, 3(6), 47. https://doi.org/10.11648/j.jhrm.20150306.11

72. Nayak, T. (2016). Impact of quality of work life on turnover intention: A study on private health care units in Odisha [Ph.D. thesis, National Institute of Technology Rourkela]. Biju Patnaik Central Library. http://ethesis.nitrkl.ac.in/8472/1/2016-PhD-TNayak-512SM302.pdf

73. Nayak, T., \& Sahoo, C. K. (2015). Quality of work life and organizational performance. Journal of Health Management, 17(3), 263-273. https://doi.org/10.1177/0972063415589236

74. Newfoundland and Labrador Statistics Agency (NLSA). (2007). Work Environment Survey: General report of results. https://www.exec.gov.nl.ca/exec/hrs/publications/work_environment_survey_2007.pdf

75. Njoroge, S. W., \& Kwasira, J. (2015). Influence of compensation and reward on performance of employees at Nakuru County Government. IOSR Journal of Business and Management, 17(11), 87-93.

76. Noor, N. M., Aziz, A. A., Mostapa, M. R., \& Awang, Z. (2015). Validation of the Malay version of the inventory of functional status after childbirth questionnaire. Bio Med Research International,2015,1-10. https://doi.org/10.1155/2015/972728

77. Nzewi, H. N., Chiekezie, O. M., \& Alphonsus, C. (2017). Workplace environment and employee performance in selected brewing firms in Anambra State. International Journal of Current Research and Academic Review, 5(1), 111-120. https://doi.org/10.20546/ijcrar.2017.501.014

78. Oludeyi, O. S. (2015). Workplace factors as determinants of job commitment among senior non-teaching staff of Olabisi Onabanjo University, Ogun State [master's thesis]. The University of Ibadan, Oyo State, Nigeria

79. Omar, M. K., Mohd, I. H., \& Ariffin, M. S. (2015). Workload, role conflict and work-life balance among employees of an enforcement agency in Malaysia. International Journal of Business, Economics, and Law, 8(2), 52-57.

80. Omotayo, A., Esther, A., \& Ibiyinka, S. (2014). Career development as a determinant of organizational growth: Modelling the relationship between these constructs in the Nigerian Banking Industry. American International Journal of Social Science, 3(7), 67-76.

81. Parker, D. F., \& Decotiis, T. A. (1983). Organizational determinants of job stress. Organizational Behavior and Human Performance, 32(2), 160-177. https://doi.org/10.1016/0030-5073(83)90145-9

82. Rahlin, N.A., Awang, Z., Afthanorhan, A., \& Aimran, N. (2019). Antecedents and Consequences of Employee Safety Climate in Small Manufacturing Enterprises: Translation, Validation and Application of Generic Safety Climate Questionnaire. International Journal of Innovation, Creativity and Change, 7(10).

83. Rahlin, N.A., Awang, Z., Zulkifli, A.R., and Bahkia, A.S (2020). The Impact of Employee Safety Climate on Safety Behavior in Small and Medium Enterprises: An Empirical Study. Humanities \& Social Science Reviews, 8(3), 2020, 163-177. https://doi.org/10.18510/hssr.2020.8318

84. Rahlin, N.A., Awang, Z., Zulkifli, A.R. and Bahkia, A.S. (2020a). The Direct Effect of Climate Emergence and Safety Climate on Intention to Safety Behavior. Humanities \& Social Science Reviews, 8(3), 2020, 178-189. https://doi.org/10.18510/hssr.2020.8319

85. Rahman, M. M., Abdul, M., Ali, N. A., Uddin, M. J., \& Rahman, M. S. (2017). Employees' retention strategy on quality of work life (QWL) dimensions of private commercial banks in Bangladesh. Pertanika Journal of Social Science and Humanities, 25(2), 647-662.

86. Rahman, R. A., Mustaffa, W. S. W., Wahid, H. A., \& Yunus, N. K. Y. (2019). Exploring the factors affecting quality of work life among millennial academic staff in Malaysian public universities. International Journal of Asian Social Science, Asian Economic and Social Society, $\quad$ 379-389. https://doi.org/10.18488/journal.1.2019.96.379.389

87. Ramawickrama, J., Opatha, H. H. D. N. P., \& Pushpakumari, M. D. (2018). Quality of work life and job performance: Empirical evidence from station masters working at Sri Lanka railways. Sri Lankan Journal of Human Resource Management, 8(1), 1-22. https://doi.org/10.4038/sljhrm.v8i1.5638

88. Ramli, N., Zainol, Z. A., Aziz, J. A., Ali, H. M., Hassim, J., Hussein, W. M. H. W., Yaakob, N. I. (2013). The concept of Research University: The implementation in the context of Malaysian University System. Asian Social Science, 9(5),307-317. https://doi.org/10.5539/ass.v9n5p307 
89. Reddy, L., \& Reddy, M. (2013). Quality of work life of employees: Emerging dimensions. Asian Journal of Management Research, 2 (2), 827-839.

90. Rekhi, S., \& Sharma, P. (2018). A study on quality of work life (QWL) in PSPCL. International Journal of Research in Management, Economics and Commerce, 8(2), 71-75. https://doi.org/10.5958/2249877X.2018.00018.8

91. Rethinam, G., \& Ismail, M. (2008). Constructs of quality of work life: A perspective of information and technology professionals. European Journal of Social Sciences, 7(1), 58- 70.

92. Robbins, S. R., \& Judge, T. A. (2013). Organizational behavior (15th ed.). Pearson.

93. Rovai, A. P., Baker, J. D., \& Ponton, M. K. (2014). Social science research design and statistics: A practitioner's guide to research methods and IBM SPSS. Watertree Press LLC.

94. Salah, M. R. (2016). The impact of training and development on employees' performance and productivity. International Journal of Management Sciences and Business Research, 5(7), 36-70.

95. Sanyal, S., Hisam, M. W., \& Baomar, Z. A. (2018). Loss of job security and its impact on employee performance A study in sultanate of Oman. International Journal of Innovative Research and Growth,7(6), 202-212. https://doi.org/10.26671/IJIRG.2018.6.7.101

96. Sehgal, S. (2012). Relationship between work environment and productivity. International Journal of Engineering Research and Applications, 2(4), 1992-1995.

97. Serey, T. T. (2006). Choosing a robust quality of work life. Business Forum, 27(2), 7-10.

98. Shariffuddin, S., Razali, J., Shaaidi, W. R. W., \& Ibrahim, I. S. A. (2017). Transformation of higher education institutions in Malaysia: A transformation of higher education institutions in Malaysia: A review. Journal of Global Business and Social Entrepreneurship (GBSE), 1(2), 126-136.

99. Sheriff, N. M., \& Abdullah, N. (2017). Research universities in Malaysia: What beholds? Asian Journal of University Education, 13(2), 35-50.

100.Shkeer, A.S., \& Awang, Z. (2019). Exploring items for measuring marketing information system construct: An exploratory factor analysis. International Review of Management and Marketing, 9(6), 87-97. https://doi.org/10.32479/irmm.8622

101.Sojka, L. (2014). Specification of the quality of work life characteristics. Sociologic, 46(3), 283-299.

102.Sultan, M. F., Zafar, M. R., \& Anila. (2016). Office design and its impact on employees' productivity: evidence from Islamic banks of Karachi. International Journal of Scientific and Research Publications, 6(6), 335-342.

103.Vadivel, S., \& Velmurugan, R. (2017). Quality of work life of employees in private companies with reference to Coimbatore. International Journal of Multidisciplinary Research and Development, 4(5), 128-131.

104.Waghmare, S., \& Dhole, V. (2017). Quality of work life and influencing factors. International Journal of Advanced Research, 5(5), 1328-1332. https://doi.org/10.21474/IJAR01/4252

105.Wan, C. D., Sirat, M., \& Razak, D. (2015). The idea of a University: Rethinking the Malaysian context. Humanities, 4(3), 266-282. https://doi.org/10.3390/h4030266

106.Williams, M. L., Malos, S. B., \& Palmer, D. K. (2002). Benefit system and benefit level satisfaction: An expanded model of antecedents and consequences. Journal of Management, 28(2), 195-215. https://doi.org/10.1016/S01492063(01)00135-0

107.Wong, P. Y., Bandar, N. F. A., \& Saili, J. (2017). Workplace factors and work-life balance among employees in selected services sector. International Journal of Business and Society, 18(S4), 677-684.

108. Yahaya, T., Idris, K., Suandi, T., \& Ismail, I. (2018). Adapting instruments and modifying statements: The confirmation method for the inventory and model for information sharing behavior using social media. Management Science Letters, 8(5), 271-282. https://doi.org/10.5267/j.msl.2018.4.021

109. Yamoah, E. E. (2014). Exploratory analysis of compensation and employee job satisfaction. Developing Country Studies, 4(12), 27-35.

110. Yazit, N., \& Zainab, A. N. (2007). Publication productivity of Malaysian authors and institutions in LIS. Malaysian Journal of Library \& Information Science, 12(2), 35-55.

111.Yu, T., \& Richardson, J. C. (2015). An exploratory factor analysis and reliability analysis of the student online learning readiness (SOLR) instrument. Online Learning, 19(5), 1-22. https://doi.org/10.24059/olj.v19i5.593

112.Zhong, L., Wayne, S. J., \& Liden, R. C. (2015). Job engagement, perceived organizational support, highperformance human resource practices, and cultural value orientations: A cross-level investigation. Journal of Organizational Behavior, 37(6), 823-844. https://doi.org/10.1002/job.2076 